\title{
Activation of Secretagogue Independent Gastric Acid Secretion via Endothelial Nitric Oxide Synthase Stimulation in Rats
}

\author{
Alice Miriam Kitay ${ }^{a, b} \quad$ Alexander Link ${ }^{b} \quad$ John P. Geibel ${ }^{a}$ \\ aDepartment of Surgery, Yale University, School of Medicine, New Haven, Connecticut, U.S.A; \\ ${ }^{b}$ Department of Gastroenterology, Hepatology and Infectious Diseases, Otto-von-Guericke University \\ Magdeburg, Germany
}

\section{Key Words}

Stomach $\bullet$ Reflux $\bullet \mathrm{H}^{+} \cdot \mathrm{K}^{+}$ATPase $\bullet$ Nitric Oxide $\bullet \mathrm{PH}$

\begin{abstract}
:
Background/Aims: L-arginine is an important mediator of cell division, wound healing, and immune function. It can be transformed by the nitric oxide synthase (NOS) to nitric oxide (NO), an important cell signaling molecule. Recent studies from our laboratory demonstrate specific effects of L-arginine $(10 \mathrm{mM})$ exposure on gastric acid secretion in rat parietal cells. Methods: Studies were performed with isolated gastric glands and the $\mathrm{pH}$ sensitive dye BCECF-AM +/- L-arginine to examine its effects on acid secretion. The direct NO-donor diethylamine NONOate sodium salt hydrate, was also used while monitoring intracellular $\mathrm{pH}$. The specific inhibitor of the intracellular NO signal cascade ODQ was also used. Results: We found that gastric proton extrusion was activated with application of L-arginine $(10 \mathrm{mM})$, in a separate series when L-arginine $(10 \mathrm{mM})+\mathrm{L}-\mathrm{NAME}(30 \mu \mathrm{M})$ were added there was no acid secretion. Addition of the NO-donor diethylamine NONOate sodium salt hydrate $(10 \mu \mathrm{M})$ also induced acid secretion. When the selective SGC-inhibitor ODQ was added with NONOate we did not observe acid secretion. Conclusion: We conclude that L-arginine is a novel secretagogue, which can mediate gastric acid secretion. Furthermore, the intake of $L$-arginine causes direct activation of the $\mathrm{H}^{+}, \mathrm{K}^{+}$ATPase and increased proton extrusion from parietal cells resulting in the increased risk for acid-related diseases. The NO/sGC/cGMP pathway has never been described as a possible intracellular mechanism for $\mathrm{H}^{+}, \mathrm{K}^{+}$ATPase activation before and presents a completely new scientific finding. Moreover, our studies demonstrate a novel role for L-NAME to effectively eliminate NOS induced acid secretion and thereby reducing the risk for L-arginine inducible ulcer disease.
\end{abstract}




\section{Cellular Physiology Cell Physiol Biochem 2017;44:1606-1615

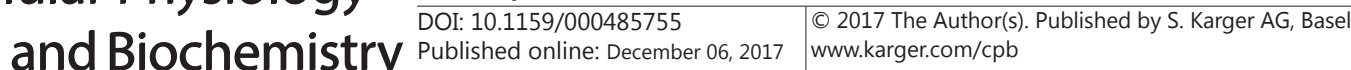

Kitay et al.: Enos Stimulation and Acid Secretion

\section{Introduction}

L-arginine belongs to the semi-essential amino acids [1] and is the sole endogenous nitrogen carrying substrate for endothelial nitric oxide (NO) synthesis by the nitric oxide synthase (NOS) [2-4]. Next to NO synthesis, L-arginine serves as the substrate for the enzymatic transformation of agmatine, creatine and urea in the human body [4, 5]. As the only precursor and nitrogen donor for nitric oxide (NO), L-arginine plays a central role in the form of a messenger in several physiological and pathophysiological processes [6-9]. Thus, L-arginine can be considered as a signaling molecule, which is responsible for the maintenance of essential cellular functions e.g. protein synthesis, cell death and growth [4, $10,11]$. As a semi-essential amino acid, L-arginine can be provided by an endogenous and an exogenous source. The kidney can subsist a basal L-arginine de-novo synthesis [4, 12], but especially during a high L-arginine demand, like growth, inflammation or wound healing processes, L-arginine-rich food intake is pivotal for the sustain of an adequate supply $[4,13$, 14]. Hence, a dietary intake of L-arginine of $1-3 \mathrm{~g} / \mathrm{d}$ through food is recommended $[4,15]$. The import of the hydrophobic amino acid through biological membranes occurs through a variety of transportation systems within the lipid bilayer. The arginine uptake in the parietal cell of the gastric gland can be $\mathrm{Na}^{+}$-independent or $\mathrm{Na}^{+}$-dependent. The cationic amino acid transporter (CAT), the hetero(di)meric amino acid transporter (HAT) and the peptide transporter (PEPT) are responsible for the intracellular uptake of L-arginine. The isoforms of the CAT have a broad expression and are ubiquitously represented $[16,17]$. They work $\mathrm{Na}^{+}-$ independent and equally transport other amino acids into the cell, e.g. ornithine and lysine [18]. HATs, especially the isoform $\mathrm{rBAT} / \mathrm{b}^{0,+}$, are responsible for a transepithelial cationic amino acid exchange between cells and PEPT1 and PEPT2 are $\mathrm{H}^{+}$dependent transporters of di- and tripeptides $[19,20]$. For further information about L-arginine transporters, please refer to the elegant review of Closs et al. (Ref. 4) 'Plasma Membrane Transporters for Arginine'. Once L-arginine resides in the cell, the NOS converts it into NO and the byproduct L-citrulline [21]. Different types of NOS exist, which vary in distinct location and function: eNOS (NOS-3, endothelial), nNOS (NOS-1, neuronal) and iNOS (NOS-2, inducible) [22, 23]. Evidence about a mitochondrial NOS have been reported, but scientists couldn't identify structure and function to date $[23,24]$. The endothelial nitric oxide synthase (eNOS) is responsible for the regulation of blood pressure and angiogenesis through intracellular signaling transductions $[22,25,26]$ whereas the neuronal NOS (nNOS) is involved in neurotransmission, learning processes and synaptic plasticity $[3,25]$. The isoforms eNOS and nNOS are acting via a calcium dependent pathway and regulate neuronal, and vascular processes through calmodulin binding [23]. The third isoform of the NOS system, the inducible NOS (iNOS) plays an important role in innate immune responses and antipathogenic processes during infections with viruses and bacteria $[25,27,28]$, and modulates tumor development $[22,25,28]$. The iNOS system is calcium-independent and produces high amounts of gas and radicals respectively, forming a cytotoxic microenvironment within the cell, which can be found during infection and tumor development [7]. NO is considered as one of the most important intracellular signaling molecules [21]. It is responsible for blood flow regulation and leads to vasodilatation [7, $23,29]$ and inhibition of platelets aggregation [23, 30]. Besides, NO is a crucial trigger for cardiac development during embryogenesis [31]. Activation of the intracellular receptor NO-GC through NO leads to an increase of soluble guanylyl cyclase (sGC) and further to accumulation of cyclic guanosine monophosphate (cGMP) [31, 32]. We hypothesize, that L-arginine stimulated gastric acid secretion in parietal cells occurs through the NO/NOGC/cGMP signaling pathway and can increase the risk for all acid-related diseases such as peptic ulcer disease (GUD), non-erosive reflux disease (NERD), gastroesophageal reflux disease (GERD) to the point of the development of gastric and esophageal malignancies. Thus, L-arginine can be considered as a potential causative agent for these gastrointestinal diseases and excessive L-arginine intake can lead to severe disadvantages for the stomach. Other, well-known causes are non-steroidal anti-inflammatory drugs (NSAIDs), nicotine, alcohol, caffeine, stress and infections [33-36]. Since the prevalence of gastroesophageal 
Kitay et al.: Enos Stimulation and Acid Secretion

ailments is continuously increasing in the United States [37], new findings about causative agents are of highly interest.

The present study focuses on intracellular changes of $\mathrm{pH}$ recovery rate following L-arginine application and provides detailed information about the mechanism and intracellular characteristics of the L-arginine induced gastric acid secretion. We have chosen L-NAME as a non-selective NOS inhibitor and were able to prevent gastric secretion by inhibiting the L-arginine stimulated NO/NO-GC/cGMP signaling pathway in the parietal cell.

\section{Materials and Methods}

Animals and preparation of the stomach

We used male Sprague-Dawley rats with a weight of 250-400g (Charles River Laboratory), housed in climate and humidity controlled light-cycled rooms, fed standard chow with ad lib access to water $24 \mathrm{~h}$. Animals were handled according to the humane practices of Animal Care established by the Institutional Animal Care and Use Committee at Yale University. Animals were food deprived for 12-16h with ad lib access to water before being euthanized with an overdose of isoflurane. We performed a laparotomy, removed the stomach and separated the corpus of the stomach with a longitudinal incision. After the isolation of the corpus, it was washed with ice-cold HEPES buffered Ringer solution to remove residual food particles and was sliced it into $0.2 \mathrm{~cm}$ square tissue sections. The procedure, including gastrectomy was executed quickly and small tissue sections were kept on ice in a petri dish filled with ice-cold HEPES buffered Ringer solution to guarantee vitality and cell function of the gastric glands [38].

\section{Hand-dissection and isolation of gastric glands}

Single sections of the corpus were transferred to the stage of a dissecting microscope and isolation of individual glands was carried out with the hand-dissection technique as described previously [39, 40]. Briefly, the corpus was cut into $2 \mathrm{~cm} \times 2 \mathrm{~cm}$ squares and then each square was further cut into single $1 \mathrm{cmx} 1 \mathrm{~cm}$ sections. The muscle layer was dissected off the section in a bath of ice cold Ringer buffer solution at $4^{\circ} \mathrm{C}$. Individual gastric glands were dissected from these sections and then transferred in cold Ringer solution to the perfusion chamber. Gastric glands were allowed to adhere to coverslips coated with $0.5 \mu \mathrm{l}$ of the biological adhesive Corning CellTak (Collaborative Research, MA, USA), a widely-used and well known polyphenolic protein-based tissue adhesive, that can strongly bind inorganic as well as organic surfaces in hydrous environment [41]. Accordingly, coverslips were attached to a perfusion chamber as previously outlined $[37,39]$. A minimum of 4-6 glands were transferred to the coated coverslips prior to dye loading.

\section{Digital Imaging for intracellular $\mathrm{pH}$ measurements}

The isolated gastric glands were incubated in a room tempered HEPES-buffered Ringer's solution containing $10 \mu \mathrm{M}$ of the pH-sensitive dye BCECF-AM(2', $\left.7^{\prime}\right)$-bis-(2-carboxyethyl)-5-(and-6)-carboxyflourescin-acetomethylester (Santa Cruz Biotechnology, TX, USA) for 20min. Following dye incubation, the perfusion chamber was placed on the stage of an inverted microscope (Olympus IX50) and flushed with a HEPES-buffered Ringer's solution for 5 minutes to remove residual non-de-esterified dye. During this flushing phase, the temperature of the chamber and the perfusate were raised to $37^{\circ} \mathrm{C}$. The chamber was thermostatically controlled and maintained for the remainder of the study at $37^{\circ} \mathrm{C}$. The epifluorescence mode with an $\times 40$ objective was used and the BCECF loaded gland was excited at the wavelengths of $490 \mathrm{~nm}$ $\pm 10 \mathrm{~nm}$ and $440 \mathrm{~nm} \pm 10 \mathrm{~nm}$. A minimum of 8 regions of interest were outlined per gland and simultaneously monitored during the whole experimental procedure. The resultant fluorescent signals of BCECF were successfully monitored at a wavelength of $530 \mathrm{~nm} \pm 10 \mathrm{~nm}$ every $10 \mathrm{sec}$ with the help of an intensified chargecoupled device camera. Individual images and intensity values were recorded along with the emission data showing the 490/440 ratio for real-time intensity measurements [37]. At the end of each experimental cycle, cells were calibrated with the High $\mathrm{K}^{+} /$nigericin calibration technique to convert all ratiometric data and calculate the intracellular $\mathrm{pH}$ from the emission data as described in previous studies [42].

The recovery of intracellular $\mathrm{pH}\left(\mathrm{pH}_{\mathrm{i}}\right)$ from an acid load demonstrates the rate of proton extrusion by individual parietal cells after acid/proton loading using the $\mathrm{NH}_{4} \mathrm{Cl}$ prepulse technique [39]. Therefore, the cells were superfused with a HEPES-buffered solution containing $40 \mathrm{mM} \mathrm{NH}_{4} \mathrm{Cl}$ to load the cells with 


\section{Cellular Physiology Cell Physiol Biochem 2017;44:1606-1615 \begin{tabular}{ll|l} 
and Biochemistry Published online: December 06, 2017 & $\begin{array}{l}\text { (c) } 2017 \text { The Author(s). Published by S. Karger AG, Basel } \\
\text { www.karger.com/cpb }\end{array}$
\end{tabular}

hydrogen ions. Parietal cells were subsequently flushed with $\mathrm{Na}^{+}$free solution to eliminate activation the Na-H-Exchanger (NHE) and trapping protons within the cytosol causing a strong drop of $\mathrm{pH}_{\mathrm{i}}$. Cells were then flushed with HEPES and finally with the High $\mathrm{K}^{+}$calibration solution to clamp intracellular $\mathrm{pH}$ to 7.0. Recovery rates were expressed in $\mathrm{dpH}_{\mathrm{i}} / \mathrm{dT}(\Delta \mathrm{pH} / \mathrm{min})$ for all studies following the conversion of the ratio data using the Henderson-Hasselbach Equation as previously described $[43,44]$. The observed recovery rate of intracellular $\mathrm{pH}\left(\mathrm{pH}_{\mathrm{i}}\right)$ represents proton extrusion by the parietal cells. Intracellular $\mathrm{pH}_{\mathrm{i}}$ recovery rates were calculated from the same initial starting $\mathrm{pH}$ to eliminate variation in individual intracellular buffering power of the cells under different experimental conditions. Recovery rates are expressed in $\Delta \mathrm{pH} / \mathrm{min}$.

\section{Chemicals and reagents}

Temperature and $\mathrm{pH}$ of all solutions (see Table 1) were adjusted to $37^{\circ} \mathrm{C}$ and 7.4 , with the exception of High $\mathrm{K}^{+}$calibration solution, which was titrated to 7.0. The final osmolality of all solutions was $300 \mathrm{mOsm}$. All chemicals, including L-arginine, L-NAME (NG-nitro-l- arginine methyl ester), Carbachol, ODQ (1H-[1, 2,4]0xadiazolo[4, 3-a]quinoxalin-1-one) and diethylamine NONOate sodium salt hydrate were obtained from Sigma Aldrich (St. Louis, MO, USA) and J.T. Baker (Phillipsburg, NJ, USA).

\section{Statistical analysis}

Graphpad/ Prism 7.0 software was used to analyze differences in $\mathrm{pH}_{\mathrm{i}}$ recovery rates. We performed the unpaired, parametric Student's t-tests to exemplify significant differences in $\mathrm{pH}_{\mathrm{i}}$ recovery rates. $\Delta \mathrm{pH} / \mathrm{min}$ values are presented as mean \pm SEM. All results with $\mathrm{p}<0.05$ were considered to be significant.

\section{Results}

To examine the rapid cellular effect of L-arginine on acid secretion, studies were performed using the isolated gastric gland preparation. In the absence of any stimulation (Control), a low-basal rate of $\mathrm{pH}_{\mathrm{i}}$ recovery was observed $(0.0003711 \pm 0.0006969$ $\Delta \mathrm{pHi} / \mathrm{min})$.

In the first series of experiments, gastric glands superfused with L-arginine $(10 \mathrm{mM})$ containing solutions were able to induce secretory stimulation resulting in an elevation of the $\mathrm{pH}_{\mathrm{i}}$ recovery rate $(0.02999$ $\pm 0.002718 \Delta \mathrm{pH} / \mathrm{min}$ ) (Fig.1).

A highly significant difference in proton extrusion can be noticed in L-arginine experiments compared to control conditions $(\mathrm{p}<0.0001)$.
Table 1. Solutions. Concentrations are expressed in millimolars

\begin{tabular}{|c|c|c|c|c|}
\hline & HEPES & $\mathrm{NH}_{4} \mathrm{Cl}$ & $\mathbf{0 N a}^{+}$ & HighK $^{+}$ \\
\hline $\mathrm{NaCl}$ & 117 & 77 & 0 & 0 \\
\hline $\mathrm{KCl}$ & 5 & 5 & 5 & 105 \\
\hline $\mathrm{NH}_{4} \mathrm{Cl}$ & 0 & 40 & 0 & 0 \\
\hline $\mathrm{CaCl}_{2} * 7 \mathrm{H}_{2} \mathrm{O}$ & 1 & 1 & 1 & 1 \\
\hline $\mathrm{MgSO}_{4} * 7 \mathrm{H}_{2} \mathrm{O}$ & 1,2 & 1,2 & 1,2 & 1,2 \\
\hline HEPES & 32,2 & 32,2 & 32,2 & 32,2 \\
\hline Glucose & 10 & 10 & 10 & 0 \\
\hline$N M D G$ & 0 & 0 & 132,8 & 32,8 \\
\hline Mannitol & 0 & 0 & 0 & 5 \\
\hline
\end{tabular}

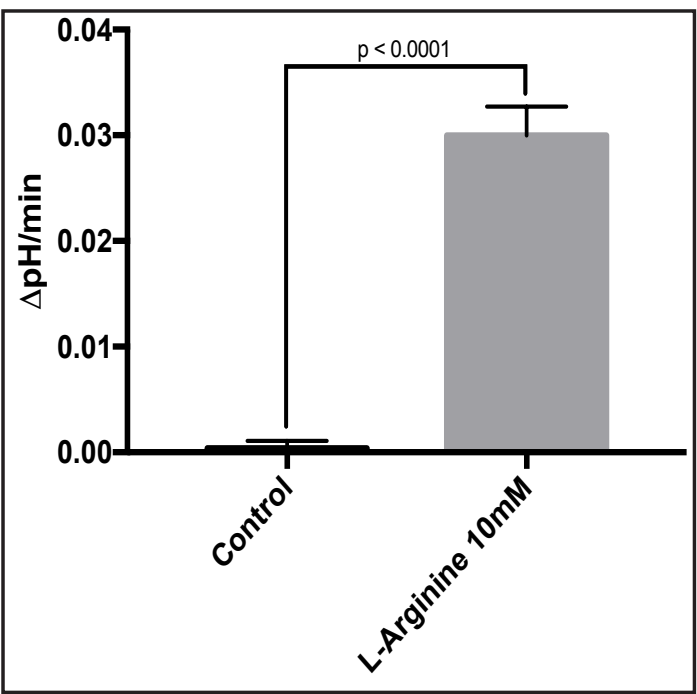

Fig. 1. L-arginine activates gastric acid secretion. Bar graph summarizes the effect of L-arginine $10 \mathrm{mM}$ on resting parietal cells $(0.02999 \pm 0.002718$ $\mathrm{pH} / \mathrm{min})(\mathrm{n}=146)$. Isolated gastric glands of rats were loaded with the $\mathrm{pH}$ sensitive dye BCECF and excited at $490 \mathrm{~nm} \pm 10 \mathrm{~nm}$ and $440 \mathrm{~nm} \pm 10 \mathrm{~nm}$. The recovery rate of $\mathrm{pH}_{\mathrm{i}}$ was calculated from the slope in the absence of $\mathrm{Na}^{+}$after acid loading, using the $\mathrm{NH}_{4} \mathrm{Cl}$ prepulse technique [39]. The control shows a low basal proton efflux of the resting parietal cell in the absence of stimulatory agents $(0.0003711 \pm$ $0.0006969 \Delta \mathrm{pHi} / \mathrm{min})(\mathrm{n}=66)$. 


\section{Cellular Physiology Cell Physiol Biochem 2017;44:1606-1615 \begin{tabular}{ll|l} 
and Biochemistry Published online: December 06, 2017 & $\begin{array}{l}\text { (c) } 2017 \text { The Author(s). Published by S. Karger AG, Basel } \\
\text { www.karger.com/cpb }\end{array}$
\end{tabular}

In a separate series of experiments, we used solutions that contained a combination of L-NAME $(30 \mu \mathrm{M})$ and L-arginine $(10 \mathrm{mM})$. Our results show that we can achieve a significant decrease in L-arginine induced gastric acid secretion in the presence of the non-selective NOS inhibitor L-NAME compared to L-arginine dependent gastric acid secretion in the absence of L-NAME $(0.002185 \pm 0.0004337 \Delta \mathrm{pH} / \mathrm{min}$ vs. $0.02999 \pm 0.002718 \Delta \mathrm{pH} / \mathrm{min}, \mathrm{p}<0.0001$ ) (Fig. 2).

In another set of experiments, we induced a stimulatory effect of proton extrusion with the classical secretagogue carbachol $(200 \mu \mathrm{M})$ and obtained $\mathrm{a} \mathrm{pH}_{\mathrm{i}}$ recovery rate of 0.03291 $\pm 0.002645 \Delta \mathrm{pH} / \mathrm{min}$. To see, if the proton extrusion by carbachol is sensitive to L-NAME, we added L-NAME $(30 \mu \mathrm{M})$ to the carbachol containing solutions. The carbachol sensitive proton extrusion was not inhibited by L-NAME and recovery rates did not show a significant difference in $\mathrm{pH}_{\mathrm{i}}$ compared to carbachol dependent gastric acid secretion in the absence of L-NAME $(0.03291 \pm 0.0026450 \Delta \mathrm{pH} / \mathrm{min}$ vs. $0.03362 \pm 0.0040260 \Delta \mathrm{pH} / \mathrm{min}, \mathrm{p}=\mathrm{ns}$ ) (Fig. 3).

We compared the $\mathrm{pH}_{\mathrm{i}}$ recovery rates of L-NAME $(30 \mu \mathrm{M})+\mathrm{L}$-arginine $(10 \mathrm{mM})$ to L-NAME $(30 \mu \mathrm{M})+$ carbachol $(200 \mu \mathrm{M})$, demonstrating a highly significant difference in gastric acid secretion $(0.002185 \pm 0.0004337$ vs. $0.03362 \pm$ $0.0040260 \Delta \mathrm{pH} / \mathrm{min}, \mathrm{p}=0.0001$ ) (Fig. 4)

In a final series of experiments, we verified our hypothesis, that L-arginine acts through the intracellular NO pathway in gastric glands. Therefore, we added the direct NO donor diethylamine NONOate sodium salt hydrate $10 \mu \mathrm{M}$ to our solutions [45]. The application of the $\mathrm{NO}$ donor resulted in increased $\mathrm{H}^{+}$ extrusion from the parietal cell $(0.03093 \pm$ $0.002054 \Delta \mathrm{pH} / \mathrm{min}$ ). By adding the potent and selective inhibitor of nitric oxide sensitive guanylyl cyclase inhibitor ODQ $(1 \mathrm{H}-[1,2,4]$ Oxadiazolo [4, 3-a]quinoxalin-1-one) $(10 \mu \mathrm{m})$ to our diethylamine NONOate sodium salt hydrate containing solutions, we were able to abolish the effect on $\mathrm{H}^{+}, \mathrm{K}^{+}$ATPases activation to a basal level $(0.00009813 \pm 0.0006929 \Delta \mathrm{pH} / \mathrm{min})$. Interestingly, we preserved nearly identical results for proton extrusion with a combination of ODQ $(10 \mu \mathrm{M})$ and L-arginine $(10 \mathrm{mM})$ containing solutions $(0.001077 \pm 0.00048 \Delta \mathrm{pH} /$ min) (Fig. 5).

Our results evidence, that observations are due to NO formation accordingly mediated

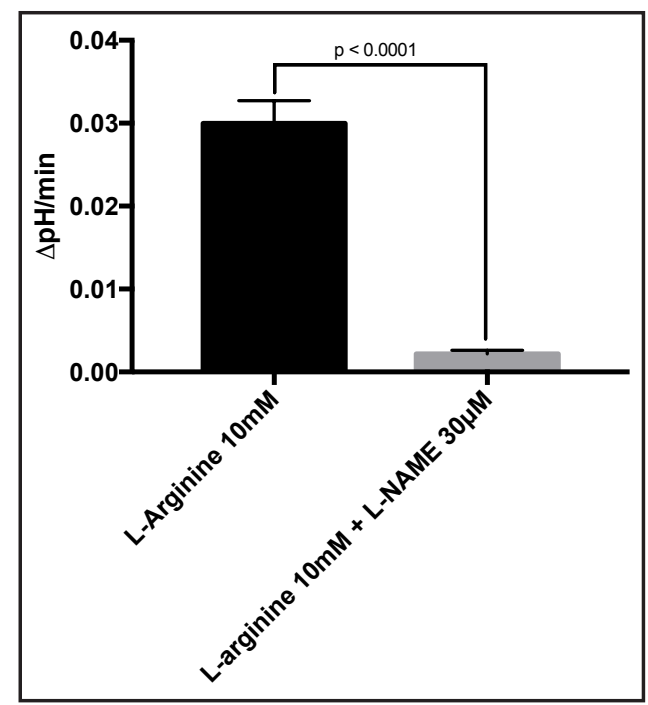

Fig. 2. L-NAME can inhibit L-arginine induced gastric acid secretion. After adding the non-selective NOS inhibitor L-NAME to our solutions, results demonstrate a low basal proton efflux of the resting parietal cell in the presence of the stimulatory agent L-arginine $(0.002185 \pm$ $0.0004337 \Delta \mathrm{pH} / \mathrm{min})(\mathrm{n}=179)$.

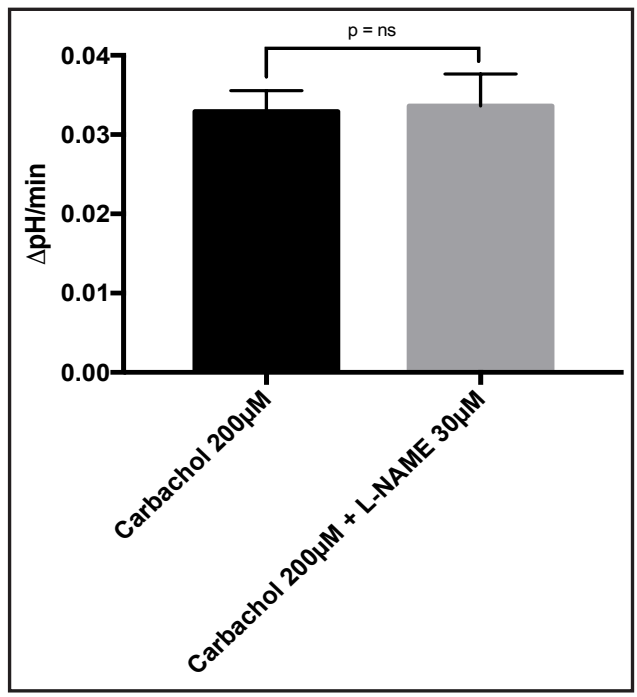

Fig. 3. Bar graph compares the effect of the classical secretagogue carbachol on rat gastric glands (0.03291 $\pm 0.0026450 \Delta \mathrm{pH} / \mathrm{min})$ $(n=168)$ to a combination of carbachol and LNAME together $(0.03362 \pm 0.0040260 \Delta \mathrm{pH} /$ $\min )(n=104)$. Our results demonstrate, that carbachol-induced gastric acid secretion cannot be suppressed by the NOS inhibitor LNAME. We conclude, that L-arginine and carbachol differ in their intracellular pathway leading to the assembly and final activation of the $\mathrm{H}^{+}, \mathrm{K}^{+}$ATPase. 


\section{Cellular Physiology Cell Physiol Biochem 2017;44:1606-1615 \begin{tabular}{l|l|l} 
DOI: 10.1159/000485755 & $\begin{array}{l}\text { O 2017 The Author(s). Published by S. Karger AG, Basel } \\
\text { www.karger.com/cpb }\end{array}$ \\
\hline and Biochemistry
\end{tabular}

Fig. 4. Bar graph highlighting the difference between L-arginine and carbachol: L-arginine induced gastric acid secretion can be inhibited by L-NAME $(0.002185$ $\pm 0.0004337 \Delta \mathrm{pH} / \mathrm{min})(\mathrm{n}=179)$, whereas stimulation of acid secretion by the classical secretagogue carbachol is not preventable by L-NAME application $(0.03362 \pm 0.0040260 \Delta \mathrm{pH} / \mathrm{min})(\mathrm{n}=104)$. Thus, both agents differ in their intracellular pathway to induce secretion. Carbachol leads to an intracellular increase of cAMP levels using muscarinic receptors, which induces the insertion and activation of $\mathrm{H}^{+}, \mathrm{K}^{+}$ ATPases, whereas L-arginine induced gastric acid secretion operates via the NO/sGC/cGMP pathway, lockable by the eNOS inhibitor L-NAME.

Fig. 5. Bar graph showing the effect of a direct NO-donor. We applied the NO-donor diethylamine NONOate sodium hydrate (NONO) $10 \mu \mathrm{M}$ to our solution and results demonstrate the increase of gastric acid secretion $(0.03093 \pm 0.002054 \Delta \mathrm{pH} / \mathrm{min})$ $(\mathrm{n}=183)$. By adding the sGC-inhibitor ODQ to our NONOate containing solutions, we were able to abolish this effect completely to the level of basal proton efflux $(0.00009813 \pm 0.0006929 \Delta \mathrm{pH} / \mathrm{min})(\mathrm{n}=140)$. In addition, we combined L-arginine containing solutions with ODQ and achieved a nearly similar effect $(0.001077 \pm 0.00048 \Delta \mathrm{pH} / \mathrm{min})(\mathrm{n}=185)$. Thus, we prove that L-arginine stimulated gastric acid secretion is dependent on the intracellular NO/sGC pathway.
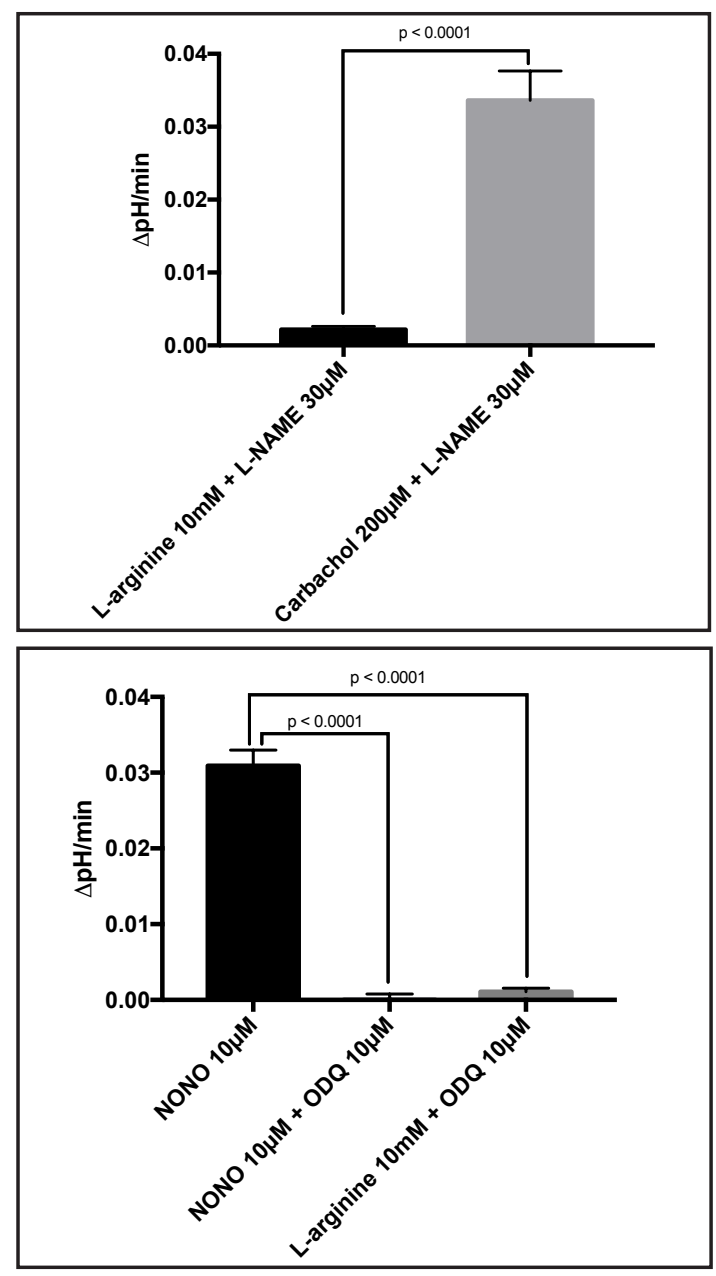

by cGMP and SGC, as L-arginine induced gastric acid secretion can be inhibited by the cellpermeable and selective sGC-inhibitor ODQ leading to an effective inhibition of cyclic GMP production.

\section{Discussion}

Our results demonstrate that L-arginine is a potent NOS activator, which can induce acid secretion via the $\mathrm{H}^{+}, \mathrm{K}^{+}$ATPase activation in resting glands or can also work in activated glands via an independent pathway (Fig. 6). Our data strongly suggest that increased levels of L-arginine in the blood following a meal can cause a continued secretion of acid from the parietal cell even in the absence of classical secretagogues, and the normal modulators of post secretagogue acid secretion (Fig.7). When we conducted a separate series of studies in the presence of the non-selective NOS inhibitor L-NAME we could prevent the L-arginine induced acid secretion. This result suggests there is an additional feedback loop linked to the generation and degradation of NO in the gastric gland that modulates acid secretion in the absence of conventional secretagogues.

This study demonstrates the novel effect of L-arginine on gastric parietal cells, its potency as a secretagogue and influence on gastric acid secretion. Moreover, we highlight the relevance of NOS in the L-arginine dependent intracellular signaling pathway, as we can abolish L-arginine induced gastric acid secretion by the application of the non-selective NOS inhibitor L-NAME. We suggest eNOS to be the important mediator involved in this process due 


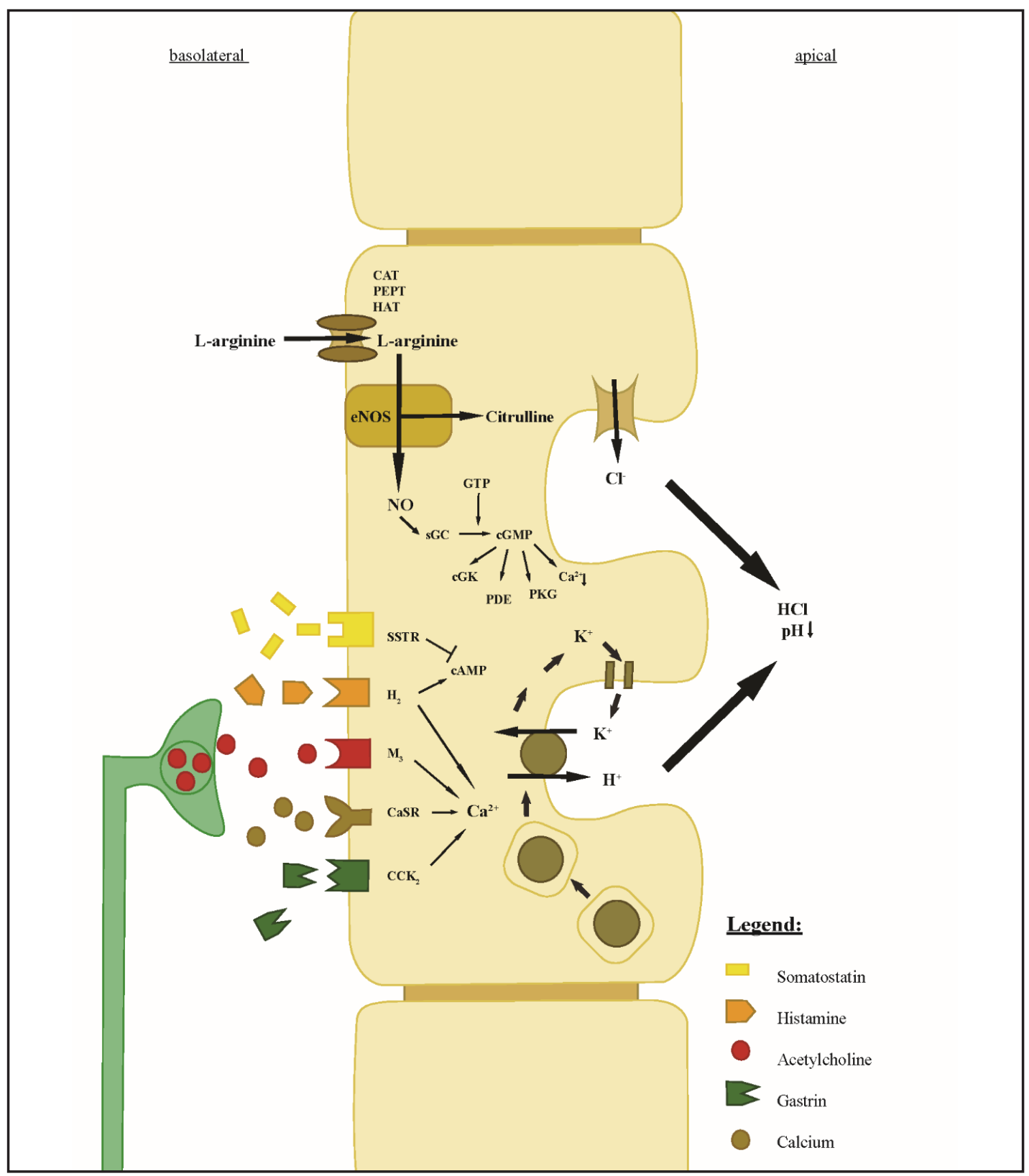

Fig. 6. Model of the parietal cell of a gastric gland. The model gives an overview of ion transporters and receptors, as well as the neuroendocrine regulation of gastric acid secretion. The components of concentrated hydrochloric acid are secreted by proton pumps $\left(\mathrm{H}^{+}, \mathrm{K}^{+}\right.$ATPases $)$and chloride channels into the gastric lumen. L-arginine enters the parietal cell through CAT, PEPT and HAT transportation systems and is enzymatically converted to the intracellular signaling molecule NO by eNOS. The increase of NO follows an increase of SGC, which gives rise in intracellular cGMP levels and ultimately leads to the insertion and activation of the $\mathrm{H}^{+}, \mathrm{K}^{+}$ATPase on the apical membrane of the parietal cell. Intracellular increase of cAMP (through histamine) or $\mathrm{Ca}^{2+}$ (through histamine, acetylcholine, $\mathrm{Ca}^{2+}$ or gastrin) following the stimulation of the basolateral receptors are having the same effect on insertion and activation of $\mathrm{H}^{+}, \mathrm{K}^{+}$ATPases like cGMP. The direct neuronal stimulation occurs by acetylcholine from the ENS, whereas the hormonal regulation of the parietal cell is dependent on vicinal, histamine-secreting ECL-cells and on the antral mucosa located Gcells, which secrete gastrin. Gastrin also stimulates histamine secretion in ECL-cells and lead to an increase of histamine secretion, which is described as the 'histamine-gastrin-axis'. Somatostatin, secreted by D-cells, decreases intracellular cAMP levels and will stop the insertion and activation of $\mathrm{H}^{+}, \mathrm{K}^{+}$ATPases.

\section{KARGER}




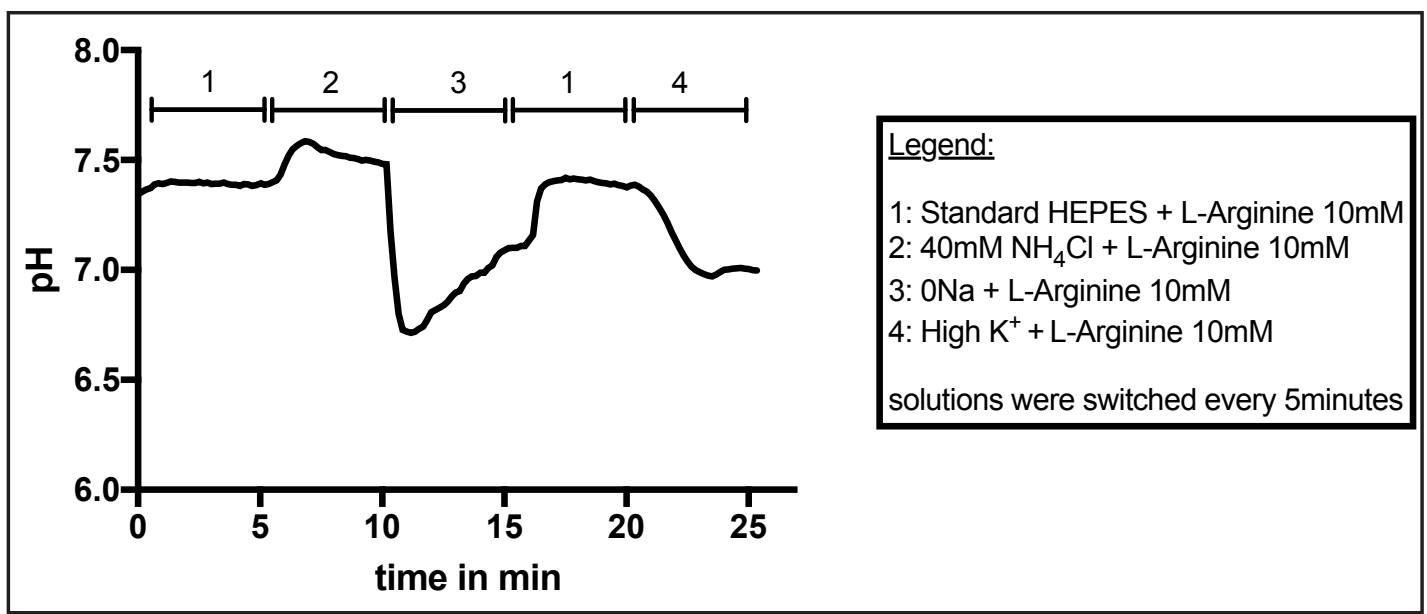

Fig. 7. Scheme of the experimental course. The graph explains an individual L-Arginine experiment (summary of all L-Arg. experiments in Fig. 1), frequency of solutions and mixture of solutions with the drug. We used Standard HEPES, $40 \mathrm{mM} \mathrm{NH}_{4} \mathrm{Cl}, 0 \mathrm{Na}$ and High $\mathrm{K}^{+}$(see composition of solutions in Tab. 1) in a combination with $10 \mathrm{mM}$ L-Arg. Solutions were switched every 5 minutes.

to the selective activators and inhibitors that we have used for our study. Furthermore, based on our long experience using isolated gastric gland preparation and previous publications, we have never had any evidence that the dissected single gland has an active neuronal circuit.

Studies by Price et al. have shown that the constitutive form of NOS is represented in the gastric mucosa [46]. The constitutive form is calcium/calmodulin dependent and implicates the endothelial (eNOS) and neuronal (nNOS) isoform [46]. The expression of nNOS in rat gastric parietal cells was confirmed by Premarante by NADPH-diaphorase histochemistry, nNOS immunostaining, Western blotting and RT-PCR and published in 2001 [47]. However, the technique used for this study differs from our: they used immunodissected glands whereas we used hand dissected glands. Expression of the isoforms change under pathological conditions, e.g. carcinogenesis or H. pylori infection of the stomach. The expression of the constitutive isoforms of NOS changed according to the stadiums of the malignancies and varied from reduction to an almost complete loss to an overexpression of the enzymes. Interestingly, iNOS was expressed in the tissue of cardia and fundus of the stomach, although it is not represented under physiological conditions [48].

The link between gastric acid secretion and the NO/NO-GC/cGMP pathway is furthermore highlighted by our diethylamine NONOate sodium salt hydrate and the SGC inhibitor ODQ experiments. The application of the direct NO-donor diethylamine NONOate sodium salt hydrate increases gastric acid secretion and verifies our hypothesis that L-arginine induced gastric acid secretion is NO-derived. Experiments with the SGC inhibitor ODQ demonstrates its potency to inhibit gastric acid secretion induced by both, NONOate or L-arginine. Thus, ODQ could become potentially a new agent against acid-related gastrointestinal diseases.

\section{Acknowledgements}

Project was funded by the Charles Ohse Surgical Research Fund Dept. of Surgery Yale University.

AMK was responsible for conducting the experiments, discussing the data, writing the manuscript, constructing the figures, interpretation of the data, statistical analysis. AL was responsible for constructive review of the final manuscript. JPG conceived the idea for responsible for experimental design, obtaining funding for the study, interpretation of the data, and review of the final manuscript. 


\section{Cellular Physiology Cell Physiol Biochem 2017;44:1606-1615 \begin{tabular}{ll|l} 
and Biochemistry Published online: December 06, 2017 & $\begin{array}{l}\text { (c) } 2017 \text { The Author(s). Published by S. Karger AG, Basel } \\
\text { www.karger.com/cpb }\end{array}$
\end{tabular}}

Kitay et al.: Enos Stimulation and Acid Secretion

\section{Disclosure Statement}

The authors declare that they have no conflicts of interest with the contents of this article.

\section{References}

1 Werner A, Amann E, Schnitzius V, Habermeier A, Luckner-Minden C, Leuchtner N, Rupp J, Closs EI, Munder M: Induced arginine transport via cationic amino acid transporter-1 is necessary for human T-cell proliferation. Eur J Immunol 2016;46:92-103.

$>2$ Figueroa A, Wong A, Jaime SJ, Gonzales JU: Influence of L-citrulline and watermelon supplementation on vascular function and exercise performance. Curr Opin Clin Nutr Metab Care 2017;20:92-98.

-3 Mungrue IN, Bredt DS: nNOS at a glance: implications for brain and brawn. J Cell Sci 2004;117:2627-2629.

4 Closs EI, Simon A, Vekony N, Rotmann A: Plasma membrane transporters for arginine. The J Nutr 2004;134:2752S-2759S; discussion 2765S-2767S.

5 Morris SM, Jr.: Enzymes of arginine metabolism. J Nutr 2004;134:2743S-2747S; discussion 2765S-2767S.

6 Albaugh VL, Pinzon-Guzman C, Barbul A: Arginine-Dual roles as an onconutrient and immunonutrient. J Surg Oncol 2017;115:273-280.

7 Vannini F, Kashfi K, Nath N: The dual role of iNOS in cancer. Redox Biol 2015;6:334-343.

8 Quinn AC, Petros AJ, Vallance P: Nitric oxide: an endogenous gas. Br J Anaesth 1995;74:443-451.

-9 Zhang N, Diao Y, Hua R, Wang J, Han S, Li J, Yin Y: Nitric oxide-mediated pathways and its role in the degenerative diseases. Front Biosci (Landmark Ed) 2017;22:824-834.

10 El-Gayar S, Thuring-Nahler H, Pfeilschifter J, Rollinghoff M, Bogdan C: Translational control of inducible nitric oxide synthase by IL-13 and arginine availability in inflammatory macrophages. J Immunol 2003;171:4561-4568.

11 Lee J, Ryu H, Ferrante RJ, Morris SM, Jr., Ratan RR: Translational control of inducible nitric oxide synthase expression by arginine can explain the arginine paradox. Proc Natl Acad Sci U S A 2003;100:4843-4848.

12 Jonker R, Deutz NE, Erbland ML, Anderson PJ, Engelen MP: Alterations in whole-body arginine metabolism in chronic obstructive pulmonary disease. Am J Clin Nutr 2016;103:1458-1464.

13 Scaglia F, Brunetti-Pierri N, Kleppe S, Marini J, Carter S, Garlick P, Jahoor F, O’Brien W, Lee B: Clinical consequences of urea cycle enzyme deficiencies and potential links to arginine and nitric oxide metabolism. J Nutr 2004;134:2775S-2782S; discussion 2796S-2797S.

14 King NE, Rothenberg ME, Zimmermann N: Arginine in asthma and lung inflammation. J Nutr 2004;134:2830S-2836S; discussion 2853S.

15 Mori M, Gotoh T: Arginine metabolic enzymes, nitric oxide and infection. J Nutr 2004;134:2820S-2825S; discussion 2853S.

16 MacLeod CL: Regulation of cationic amino acid transporter (CAT) gene expression. Biochem Soc Trans 1996;24:846-852.

17 Closs EI: Expression, regulation and function of carrier proteins for cationic amino acids. Curr Opin Nephrol Hypertens 2002;11:99-107.

18 White MF: The transport of cationic amino acids across the plasma membrane of mammalian cells. Biochim Biophys Acta 1985;822:355-374.

19 Herrera-Ruiz D, Knipp GT: Current perspectives on established and putative mammalian oligopeptide transporters. J Pharm Sci 2003;92:691-714.

20 Daniel H, Kottra G: The proton oligopeptide cotransporter family SLC15 in physiology and pharmacology. Pflugers Arch 2004;447:610-618.

21 Poulos TL, Li H: Structural basis for isoform-selective inhibition in nitric oxide synthase. Acc Chem Res 2013;46:390-398.

22 Sanhueza C, Araos J, Naranjo L, Barros E, Subiabre M, Toledo F, Gutierrez J, Chiarello DI, Pardo F, Leiva A, Sobrevia L: Nitric oxide and pH modulation in gynaecological cancer. J Cell Mol Med 2016;20:2223-2230.

23 Kone BC: Molecular biology of natriuretic peptides and nitric oxide synthases. Cardiovasc Res 2001;51:429441.

24 Ghafourifar P, Richter C: Nitric oxide synthase activity in mitochondria. FEBS Lett 1997;418:291-296.

25 Brunel A, Lang J, Couture M, Boucher JL, Dorlet P, Santolini J: Oxygen activation in NO synthases: evidence for a direct role of the substrate. FEBS Open Bio 2016;6:386-397. 


\section{Cellular Physiology Cell Physiol Biochem 2017;44:1606-1615 \begin{tabular}{ll|l} 
DOI: 10.1159/000485755 & $\begin{array}{l}\text { O 2017 The Author(s). Published by S. Karger AG, Basel } \\
\text { www.karger.com/cpb }\end{array}$
\end{tabular} \\ Kitay et al.: Enos Stimulation and Acid Secretion}

26 Sessa WC: eNOS at a glance. J Cell Sci 2004;117:2427-2429.

27 Bogdan C: Nitric oxide and the immune response. Nat Immunol 2001;2:907-916.

28 Lowenstein CJ, Padalko E: iNOS (NOS2) at a glance. J Cell Sci 2004;117:2865-2867.

29 Kozaeva LP, Gorodetskaya EA, Ruuge EK, Kalenikova EI, Medvedev OS: Beneficial effect of coenzyme Q10 injection on nitric oxide -related dilation of the rat aorta. Eur J Pharmacol 2016;794:15-19.

-30 Radomski MW, Palmer RM, Moncada S: An L-arginine/nitric oxide pathway present in human platelets regulates aggregation. Proc Natl Acad Sci U S A 1990;87:5193-5197.

-31 Spinelli V, Vona A, Corti F, Diolaiuti L, Zanardelli M, Sartiani L, Failli P: Role of Nitric Oxide, Nitric Oxide Synthase, Soluble Guanylyl Cyclase, and cGMP-Dependent Protein Kinase I in Mouse Stem Cell Cardiac Development. Stem Cells Int 2016;2016:2868323.

-32 Koesling D, Mergia E, Russwurm M: Physiological Functions of NO-Sensitive Guanylyl Cyclase Isoforms. Curr Med Chem 2016;23:2653-2665.

-33 Malfertheiner P, Chan FK, McColl KE: Peptic ulcer disease. Lancet 2009;374:1449-1461.

34 Locke GR, 3rd, Talley NJ, Fett SL, Zinsmeister AR, Melton LJ, 3rd: Risk factors associated with symptoms of gastroesophageal reflux. Am J Med 1999;106:642-649.

35 Dent J, El-Serag HB, Wallander MA, Johansson S: Epidemiology of gastro-oesophageal reflux disease: a systematic review. Gut 2005;54:710-717.

-36 Ferstl FS, Kitay AM, Trattnig RM, Alsaihati A, Geibel JP: Secretagogue-dependent and -independent transport of zinc hydration forms in rat parietal cells. Pflugers Arch 2016;468:1877-1883.

37 Kirchhoff P, Socrates T, Sidani S, Duffy A, Breidthardt T, Grob C, Viehl CT, Beglinger C, Oertli D, Geibel JP: Zinc salts provide a novel, prolonged and rapid inhibition of gastric acid secretion. Am J Gastroenterol 2011;106:62-70.

38 Busque SM, Kerstetter JE, Geibel JP, Insogna K: L-type amino acids stimulate gastric acid secretion by activation of the calcium-sensing receptor in parietal cells. Am J Physiol Gastrointest Liver Physiol 2005;289:G664-669.

39 Geibel JP, Wagner CA, Caroppo R, Qureshi I, Gloeckner J, Manuelidis L, Kirchhoff P, Radebold K: The stomach divalent ion-sensing receptor scar is a modulator of gastric acid secretion. J Biol Chem 2001;276:3954939552.

40 Boron WF, Waisbren SJ, Modlin IM, Geibel JP: Unique permeability barrier of the apical surface of parietal and chief cells in isolated perfused gastric glands. J Exp Biol 1994;196:347-360.

41 Sahai S, Wilkerson M, Zaske AM, Olson SD, Cox CS, Triolo F: A cost-effective method to immobilize hydrated soft-tissue samples for atomic force microscopy. Biotechniques 2016;61:206-209.

42 Paradiso AM, Negulescu PA, Machen TE: Na+-H+ and Cl(-)-OH-(HCO3-) exchange in gastric glands. Am J Physiol 1986;250:G524-534.

43 Boyarsky G, Ganz MB, Sterzel RB, Boron WF: pH regulation in single glomerular mesangial cells. II. Na+dependent and -independent Cl(-)-HCO3- exchangers. Am J Physiol 1988;255:C857-869.

-44 Boyarsky G, Ganz MB, Sterzel RB, Boron WF: pH regulation in single glomerular mesangial cells. I. Acid extrusion in absence and presence of HCO3 Am J Physiol 1988;255:C844-856.

45 Wang C, Kemp-Harper BK, Kocan M, Ang SY, Hewitson TD, Samuel CS: The Anti-fibrotic Actions of Relaxin Are Mediated Through a NO-sGC-cGMP-Dependent Pathway in Renal Myofibroblasts In vitro and Enhanced by the NO Donor, Diethylamine NONOate. Front Pharmacol 2016;7:91.

46 Price KJ, Hanson PJ, Whittle BJ: Localization of constitutive isoforms of nitric oxide synthase in the gastric glandular mucosa of the rat. Cell Tissue Res 1996;285:157-163.

47 Premaratne S, Xue C, McCarty JM, Zaki M, McCuen RW, Johns RA, Schepp W, Neu B, Lippman R, Melone PD, Schubert ML: Neuronal nitric oxide synthase: expression in rat parietal cells. Am J Physiol Gastrointest Liver Physiol 2001;280:G308-313.

48 Rajnakova A, Goh PM, Chan ST, Ngoi SS, Alponat A, Moochhala S: Expression of differential nitric oxide synthase isoforms in human normal gastric mucosa and gastric cancer tissue. Carcinogenesis 1997;18:1841-1845. 